\title{
Agricultural Adaptation to Highland Climate in Iron Age Anatolia
}

\author{
John M. Marston ${ }^{1, *}$ and Scott Branting ${ }^{2}$ \\ ${ }^{1}$ Department of Archaeology, Boston University, 675 Commonwealth Avenue, Boston, MA \\ 02215, USA \\ *Corresponding Author, marston@bu.edu
}

${ }^{2}$ Department of Anthropology, University of Central Florida, 309 Howard Phillips Hall, 4000 Central Florida Boulevard, Orlando, FL 32816, USA

(C) 2016. This manuscript version is made available under the Elsevier user license http://www.elsevier.com/open-access/userlicense/1.0/ 


\begin{abstract}
As polities grow and expand into environments distinct from their homeland, settlers moving to new landscapes may need to adapt familiar agricultural strategies to a new climate. This article explores one such case through the site of Kerkenes, a fortified, mountaintop urban center of Iron Age Central Anatolia evidently founded by Phrygian settlers from further west. New archaeobotanical data from Kerkenes indicate a set of agricultural practices broadly similar to that of other contemporary sites in Anatolia. Farmers at Kerkenes, however, appear to have prioritized bread wheat cultivation over that of barley, in stark contrast to agricultural strategies at Gordion, capital of the Phrygian kingdom. Placing Kerkenes in its environmental and economic landscape suggests that farmers took advantage of favorable rainfall patterns to emphasize a preferred cereal crop, deploying new strategies to minimize local subsistence risk. These results highlight the potential of regional syntheses of agricultural practices within large territorial states to illuminate the environmental footprints and agricultural signatures of individual polities.
\end{abstract}

\title{
Keywords
}

Archaeobotany, Climate adaptation, Agriculture, Iron Age, Anatolia, Wheat, Phrygia 


\section{Introduction}

The study of how large, complex polities grow and expand has been a central concern of archaeologists since the beginnings of the discipline, and for good reason-such cases offer unique insights into social and economic forces leading to complex hierarchies and regional economic networks (Alcock et al., 2009; Algaze, 2005; Sinopoli, 1994; Smith and Montiel, 2001). The economic basis of many early polities, however, was agricultural production, and all polities must find ways to feed their populations. To gain deeper insight into the processes of regional expansion that create large territorial states, we first need to understand how farmers moving into new environments, potentially with dramatically different climatic conditions from their homeland, adapt familiar agricultural systems to new climate regimes. The success of agricultural adaptations to new climates contributes to the long-term success or failure of both settlements and polities, as highlighted by case studies from areas as diverse as the desert US Southwest (Redman et al., 2009), the Maya lowlands (Dunning et al., 2012; Iannone et al., 2014), and highland southwestern China (d'Alpoim Guedes et al., 2015; d'Alpoim Guedes et al., 2014).

We can best investigate agricultural adaptation to climatic diversity through a multiproxy archaeological and paleoenvironmental approach that combines datasets from multiple contemporary sites within a polity that lie in distinct climatic zones. Such a regional and holistic perspective permits us to ask how each population adapted to their unique, local climatic and landscape conditions, and to assess whether those adaptations were successful over the long term or just short-term experiments that were quickly abandoned (Marston, 2015; Miller, 2010, p. 69; Redman and Kinzig, 2003). A regional, synchronic approach to agricultural adaptation to climate 
variation also offers valuable data with which to assess potential strategies to cope with diachronic climate change, such as that of the Late Bronze Age in the Eastern Mediterranean, to which social collapse and reorganization are often at least partially attributed (e.g., Kaniewski et al., 2010; Weiss, 1982).

This article explores agricultural systems of the Phrygian kingdom, which controlled Central Anatolia (modern Turkey) between the ninth and mid-sixth centuries BC (Roller, 2011). We present new archaeobotanical data from the short-lived highland urban site at Kerkenes Dağ (Fig. 1) and identify how Phrygian settlers, who founded the site in the later seventh century (Branting et al., in press; Summers, 2013; Summers and Summers, 2013), structured regional agricultural and land-use practices. By comparing data from Kerkenes with a contemporary archaeobotanical dataset from Gordion, the lowland Phrygian capital, we ask how farmers at Kerkenes adapted to highland climatic conditions and assess the success and sustainability of their agricultural practices. These findings reflect on the ability of the Phrygian state to expand into new areas and maintain long-term settlements in strategic areas with challenging climatic conditions, such as the Anatolian highlands.

\section{Agricultural adaptation to climate variation}

Studies of agricultural adaptation to climate change have become increasingly critical in recent years as the effects of anthropogenic global change become more evident (Foley et al., 2005; Porter et al., 2014). Archaeologists and environmental scientists point to the past as offering multiple avenues to explore adaptation to diachronic climate and environmental change. A broad suite of methods have been employed to reconstruct agricultural systems, ranging from 
the direct morphological analysis of archaeological plant (Marston et al., 2014; Pearsall, 2015) and animal remains (Arbuckle et al., 2009; Zeder, 1991) to recent advances in stable isotope analyses of plants (Fiorentino et al., 2015) and animal, as well as human, skeletons (Bentley, 2006; Warinner, 2014). When combined with paleoenvironmental reconstruction, it becomes possible to explore long-term diachronic change in agricultural systems as a response to environmental and climatic change (e.g., Miller, 2013; Riehl, 2009, 2014) and to identify the impacts of agriculture on local landscapes (e.g., Butzer, 2005; Casana, 2008; Marsh and Kealhofer, 2014).

Agricultural expansion into new climatic zones offers an alternative pathway to study adaptation to climatic change. One advantage to studying spatial variation in agricultural systems across different climatic regimes is that agricultural adaptation can be explored within the context of contemporary political and economic systems, which change over time. An excellent example of such adaptation is how farmers adapt when moving into highland environments, characterized by cooler temperatures and reduced growing seasons, as well as precipitation regimes that often differ substantially from adjacent lowlands. Recent research in southwest China has shed new light onto how highland agricultural strategies were enabled by the introduction of new crops amid ongoing Holocene climate change (Chen et al., 2015; d'Alpoim Guedes, 2015; d'Alpoim Guedes and Butler, 2014; d'Alpoim Guedes et al., 2013; d'Alpoim Guedes et al., 2015).

While highland regions of Anatolia do not reach the elevations of the Tibetan Plateau, distinct agricultural strategies were still needed for farming in the colder and wetter climatic regime of highland Central Anatolia. New archaeobotanical data from the highland Iron Age site of Kerkenes indicate a significantly different set of agricultural practices than practiced at the 
contemporary lowland site of Gordion, the capital of the Phrygian kingdom 270km to the west (Fig. 1).

\section{History and paleoclimate of Kerkenes}

The site of Kerkenes is an Iron Age city encompassing some 271 ha of planned urban blocks within a massive $7 \mathrm{~km}$ circuit wall, situated atop a mountain ridge at 1250-1490 m elevation in the highlands of eastern Central Anatolia (Figs. 1, 2). The city was likely founded in the later seventh century BC and was destroyed in the 540s BC during the conquest of Anatolia by Cyrus the Great, founder of the Achaemenid Persian Empire (Summers and Summers, 2013). There has been considerable debate regarding the settlement date of the site, which cannot be reliably determined using radiocarbon dating due the plateau on the radiocarbon calibration curve spanning the late $8^{\text {th }}$ to late $5^{\text {th }}$ centuries BCE (Reimer et al., 2013, p. 1881). This has led to speculation about the identity of the site and the polity that constructed the city, which is clearly an imperial foundation given its size and location. Evidence for a clear Phrygian cultural connection comes from epigraphic evidence, architecture, ritual installations, sculpture, and ceramics (Branting et al., in press; Summers, 2006, 2013; Summers and Summers, 2013). Many scholars now accept Kerkenes as the eastern-most expansion of the Phrygian state (Kealhofer and Grave, 2011; Roller, 2011), while others suggest that it could have been an independent polity founded by Phrygian settlers from the west (Summers, 2013).

The nature of the Phrygian economy and political system remain poorly defined, due in part to the scarcity and brevity of written records in the Phrygian language and few detailed accounts from neighboring, more verbose, polities. While a full exploration of Phrygian 
economy is beyond the scope of this study, approaches to the topic have mainly relied on archaeological data from elite structures in the core of Gordion, finds from royal funerary monuments at that site, and rock-cut cult architecture scattered across the Phrygian highlands, as well as secondary textual sources (e.g., Roller, 2011; Rose, 2012; Young, 1981). Mechanisms for centralized control of the agricultural economy at Gordion and across Phrygia remain speculative (but see Marston, 2012; Miller, 2010; Miller et al., 2009). Elites at Gordion evidently could marshal significant agricultural surpluses, presumably through a system of taxation, but the spatial extent and intensity of this control, and the degree of autonomy afforded to individual farmers residing at the site or across Phrygia, remains uncertain. As such the specific role of Kerkenes within the political and agricultural economy of the Phrygian state is unclear and awaits further study of both Gordion and its peripheral centers, including Kerkenes.

Climate in highland Central Anatolia differs substantially from that of lowland Central Anatolia. The lowland plateau is hot, relatively dry, and characterized by open steppe and “steppe-woodland" vegetation communities, with scrub woodland beginning above $900 \mathrm{~m}$ elevation and closed canopy forests above 1300m (Atalay, 1997, 2001; Marston, in press; Zohary, 1973). Highland areas of the eastern plateau are colder, relatively wet, and include both steppe and forest patches, depending on altitude. The modern city of Yozgat lies $22 \mathrm{~km}$ from Kerkenes at a similar elevation and approximates climatic conditions at that site, while Polatl1, the modern city closest to Gordion, lies 200 m higher in elevation than Gordion and overestimates precipitation while underestimating temperature at that site (Table 1). Yozgat (and Kerkenes) receive significantly more precipitation than Polatlı (and Gordion) and the ground remains frozen and snow covered for significantly more of the year, resulting in a shorter 
growing season; on average, first frosts in Yozgat occur in late October and continue through early May (Yozgat Governate Directorate of Provincial Disaster and Emergency, 2016).

It is difficult to determine exactly how the climate of Central Anatolia in the Iron Age differed from today due to the scarcity of reliable paleoclimatic records in the region, an effect of aridity that has prevented the formation of permanent lakes sufficient to preserve pollen and other laminated proxy records (Marston, in press; van Zeist and Bottema, 1991). The best data sources we do have, lake cores from Eski Acıgöl and Nar Gölü (Fig. 1), give conflicting pictures of rainfall change. Data from Eski Acıgöl suggest drying during the period at which Kerkenes was occupied (Roberts et al., 2011, p. 150), although the dating of this core is imprecise (Roberts et al., 2001, p. 733). In contrast, data from Nar Gölü indicate that the period beginning around $600 \mathrm{BC}$ featured an increasingly humid climate in relation to the particularly arid preceding period of the Late Bronze Age to Early Iron Age transition (Allcock, 2013, p. 253). A recent regional synthesis for the Eastern Mediterranean, however, characterizes the entire first millennium $\mathrm{BC}$ as somewhat drier than the present day, albeit with increasing humidity over that period (Finné et al., 2011); still, this result condenses much of the apparent regional variation among data in Central Anatolia (Marston, in press). Overall, however, these data suggest that the climate of Kerkenes was grossly similar to present conditions during occupation of the site.

\section{Materials and methods}

Two distinct contexts were excavated in 2010 and 2011 at Kerkenes. In 2010, a building postulated to be a public space, perhaps a temple, was explored in Trench 27 (Fig. 2). Trench 28 was placed across the back of this building and into a small connected structure that may have 
had a less public function (Branting, 2010, pp. 50-51, 53; Summers et al., 2012, p. 544).

Excavations at Kerkenes since 2011 have focused explicitly on domestic contexts, with the aim of exploring and elaborating household organization across the city; this includes Trench 29 within an urban block located along the northern boundary of the city (Branting et al., in press; Fig. 2). As such, most of the samples and the vast majority of botanical finds presented here are interpreted as domestic, or at least non-public, contexts.

A more extensive program of soil sampling than had previously been attempted was implemented at Kerkenes in 2010 and 2011. In 2010, while developing this new soil sampling system, point samples were taken opportunistically from contexts identified as likely to be stratigraphically intact during excavation, a probabilistic sampling strategy (d'Alpoim Guedes and Spengler, 2014). In 2011, a systematic collection system was implemented, augmented by continued probabilistic sampling, using a $1 \mathrm{~m}$ hexagonal grid lattice above, at, and below floor level contexts in Trench 29 (Figs. 2, 3). Soil samples collected in 2010 averaged 11.4 L in volume, while in 2011 standardized samples of $10 \mathrm{~L}$ were taken, as well as a few experimental, supplementary $2 \mathrm{~L}$ samples (see supplemental data file). Samples were floated in the field using a Siraf-style flotation device (Pearsall, 2015, p. 51) and light fractions were exported to Boston University for analysis with permission of the Turkish Ministry of Culture and Tourism and the Yozgat Museum; heavy fractions were hand-sorted on site. Light fractions were analyzed under stereomicroscopes and seeds identified using the modern comparative collection of Near Eastern plants at the Boston University Environmental Archaeology Laboratory.

The taphonomy of archaeological remains at Kerkenes is complex (Branting et al., in press). The combination of massive sitewide burning at high temperatures, shallow burial of many contexts, proximate bedrock, the exposed mountaintop landscape, and soil composition 
and chemistry appears to be unfavorable for preservation of some types of small finds. Pottery is often degraded, with evidence for both mechanical and chemical weathering, and animal bone is poorly preserved sitewide, as it is heavily fragmented and burned. Metals, however, are generally exceptionally well preserved, as are architectural foundations. Carbonized plant remains are not numerous in most deposits, but are well preserved when found. Shallow burial of deposits has led to considerable loss of some archaeological strata in portions of the site; for example, no intact floor deposits were identified in the public building in Trench 27 (Branting, 2010), and accordingly botanical finds from that structure are sparse (see supplementary data file). Other structures with intact destruction strata (including Trenches 28 and 29) have higher densities of charred remains. Overall, however, the charred density of remains at Kerkenes is considerably lower than that of other Iron Age sites in Anatolia, such as Gordion (Table 2). As such, we refrain from detailed spatial analysis of botanical remains at this time and focus instead on the synthesis of site-wide data to establish overall patterns of agricultural practice.

Comparative data from Gordion are drawn from the full sample-by-sample archaeobotanical dataset from the Middle Phrygian period (c. 800-540 BCE) at that site, analyzed by both Marston (in press) and Miller (2010). Summary statistics and analyses in the more recent of these publications (Marston, in press) incorporate both complete datasets. Similar to the Kerkenes assemblage, contexts excavated at Gordion include an abandoned, trash-filled cellar of a likely public building (Miller, 2010, p. 4) and several domestic structures and trash pits (Marston, in press). The Gordion samples are directly comparable to those of Kerkenes as they were collected using a similar sampling strategy, with samples of 10-15 L, using an identical Siraf-style flotation device. Gordion samples were sorted in the laboratory using the same methods and identified using a consistent set of identification criteria and the same modern 
comparative collection and botanical reference resources (e.g., Cappers et al., 2006; Davis, 19652000; Nesbitt, 2006).

Metrics for data presentation of both datasets include simple counts and weights, ubiquity, and comparative ratios (Marston, 2014; Miller, 1988; Popper, 1988; Table 2). Cereal seeds were counted when the embryo end of the seed was preserved to establish a minimum number of individuals for each taxon; pulse seeds were counted by half when at least an entire half was preserved. All wild seeds were counted only when entire; cereal rachis fragments were counted by the smallest unit fully preserved (see Marston, in press for a full description of Gordion analytical methods, which were replicated at Kerkenes). Ubiquity is calculated as the number of contexts in which a taxon appears divided by the total number of discrete analytical units excavated (Marston, 2014, p. 167; Pearsall, 2015, pp. 160-162; Popper, 1988, p. 61). In this case we have calculated ubiquity out of the total number of samples, rather than first grouping samples by excavation unit. This was done to preserve the spatial integrity of the assemblage, especially in Trench 29 at Kerkenes where samples were taken across a single destruction layer to explore spatial patterning in deposition (Fig. 3). Ubiquity for Gordion samples was calculated in the same manner, although each also originates from a discrete stratigraphic unit. Ratios were calculated as described in Table 2, generally based on the total weight of seeds, although counts are used for wild seeds. Note that although uncarbonized seeds were recovered, recorded, and identified (see supplementary data file; Marston, in press), we consider them to be almost certainly modern components of the shallow soils, so they are not included in the analyses here, which solely focus on carbonized seeds.

\section{Agricultural practices at Kerkenes}


Several types of agricultural products were identified in these samples (Table 2; supplementary data file). The most commonly identified crop seed was free-threshing wheat (Triticum aestivum or T. durum, indistinguishable using seed remains, although the only two identifiable rachis remains are both bread wheat, $T$. aestivum), present in $44 \%$ of samples. Barley, a hulled variety with at least some six-row barley (Hordeum vulgare), as a few clearly twisted grains are present, was present in $25 \%$ of samples. Pulses, including both bitter vetch (Vicia ervilia, 6.5 seeds) and lentil (Lens culinaris, two seeds), as well as unidentifiable pulse fragments, were present in only $14 \%$ of samples. These were likely grown for human consumption and, in the case of bitter vetch, also for fodder (Miller and Enneking, 2014), although the specific use context of bitter vetch at Kerkenes is not yet clear. Cereals, however, appear to have been the primary crop grown at Kerkenes, as total cereal remains (all wheat, barley, and indeterminate cereal fragments) outweigh pulse remains (a sum of all identified and indeterminate pulse fragments) by a ratio of nearly $87: 1$. This is consistent with early twentieth century ethnographic accounts of the area, in which less than $1 \%$ of unirrigated farmland was used for non-cereal crops, and only $11 \%$ of irrigated land area was planted with vetch or alfalfa, both grown solely for fodder (Morrison, 1939, pp. 46-47). There is no evidence for viticulture or arboriculture among these samples, however, in contrast to an earlier archaeobotanical study that identified numerous cornelian cherry endocarps (Cornus mas) and one cherry pit (Cerasus cf. avium) in the palatial complex of the city (Fig. 2; Smith and Branting, 2014). Certainly cornelian cherry, and possibly cherry, grew wild locally and was available for seasonal collection.

Fuel use at Kerkenes can be illuminated through the use of seed to charcoal ratios, which indicate the relative contributions of ruminant dung versus wood as fuel sources (Miller, 1997; 
Miller and Marston, 2012; Table 2). This ratio can be calculated based on total seed weight to charcoal weight, or by the count of wild seeds to charcoal weight. A low value indicates a preponderance of wood fuel use, and a high value a greater contribution of animal dung. The seed to charcoal ratio at Kerkenes $(0.02)$ is equivalent to the lowest values identified in a regional survey of Near Eastern sites and indicates that wood was the primary fuel source at Kerkenes (Miller and Marston, 2012, p. 100). Forthcoming analysis of wood charcoal remains from Kerkenes will shed additional light on wood harvesting practices and local woodland ecology during the Iron Age.

Animal husbandry at Kerkenes remains inadequately understood, due to the often poor preservation of bone at the site and the limited use of dung fuel, which renders sample sizes for analysis of animal diet relatively small. The wild seed to cereal ratio is one measure of the relative importance of foddering and grazing in animal diet; the value of 48.3 at Kerkenes is low in the context of other Near Eastern sites (Miller and Marston, 2012, p. 100), indicating a significant role of fodder in animal diet at Kerkenes, presumably during long winters. Available data suggest that barley would have been the primary fodder crop, with bitter vetch of secondary importance, although legumes are likely to be somewhat underrepresented in the archaeobotanical assemblage compared to cereals due to differential taphonomy and preservation. Comparative ethnographic data also suggests a mixture of grazing (especially in the summer, in uplands unsuitable for agriculture) and foddering (primarily in winter) for domestic animals (Morrison, 1939, pp. 8-9, 27-28, 40, 52-54; Yakar, 2000, p. 229).

It is also possible, of course, that some wild seeds arrived as crop weeds or deliberately gathered plants. An ecological analysis of the wild seed assemblage at Kerkenes discounts those possibilities in this case. The wild seed assemblage is comprised primarily of grass (Poaceae), 
sedge (Cyperaceae), and pink (Caryophyllaceae) seeds. While some specific genera of wild seeds represent species that do occur as common field weeds (e.g., Adonis, Galium, and wild Hordeum), all are native to the steppe grasslands of the area and are frequently encountered in regional survey in steppe landscapes of Central Anatolia (Marston unpublished data; cf. Davis, 1965-2000; Fırıncioğlu et al., 2007; Miller, 2010). Given the low frequency of seeds of obligate, or even persistent, crop weeds, we believe these seeds are more likely to have been incorporated into the archaeological record at Kerkenes via the combustion of dung fuel, albeit apparently infrequently at that site. Only fennel (Foeniculum vulgare) may represent deliberate collection of a wild vegetable for human consumption: all three seeds recovered come from a single area within a room that appears to contain cooking debris (Branting et al., in press), suggesting the possibility of this interpretation.

Ratios that compare crop types to one another offer insight into a variety of agricultural practices, allowing the testing of hypotheses specific to an agricultural system (Marston, 2011, 2014; Miller, 1988). One such ratio is that of hulled barley, a relatively drought-tolerant cereal, to free-threshing wheat, which has greater water requirements but higher value for human consumption; a higher ratio of barley to wheat indicates an agricultural strategy more resilient to the risk of drought (Marston, 2011). Kerkenes lies in an area with abundant rainfall, well above the minimum threshold for wheat agriculture, but occasional seasonal drought or a freeze following germination can significantly reduce wheat yields (Morrison, 1939, p. 25); barley has a shorter growing season, so is less vulnerable to hard frosts, and is preferentially planted in alpine settings in Anatolia above $2000 \mathrm{~m}$ (Yakar, 2000, pp. 287, 396). Despite the lower risk associated with barley, wheat is preferred for human consumption and has been routinely valued at a significant premium to barley since antiquity (Gallant, 1991; Halstead and Jones, 1989; Johnson, 
1936; METU, 1965, p. 64; Morrison, 1939, p. 25). This preference is evident at Kerkenes, as reflected in the barley to wheat ratio of 0.24 (roughly four times more wheat than barley by weight), similar to the predominance of wheat agriculture in this region attested ethnographically in the 1930s, when roughly 10 times more land was devoted to wheat than barley (Morrison, 1939, p. 17).

\section{Adaptation to climatic variation in Phrygian Anatolia}

Analysis of plant remains from Kerkenes indicates an agricultural strategy focused on cereal agriculture, especially the farming of wheat, likely bread wheat. Pulses were also farmed, though apparently in much smaller quantities. The presence of bitter vetch, which appears to have been both a staple foodstuff and at least at times a fodder crop during the Iron Age in Central Anatolia, provides additional adaptive potential (Miller, 2010; Miller and Enneking, 2014). In sum, we identify an agricultural strategy focused on two goals: bread wheat production and animal fodder, likely for winters. This strategy appears to have been successful: bread wheat is water-intensive but cold tolerant, suitable for autumn planting (i.e., as winter wheat), but also with a growing season short enough to allow spring planting if a dry winter or late spring frost damaged the winter crop. Barley was likely not routinely needed as a risk-mitigating counterpart for human subsistence in this system, as a balance between winter and spring wheat provided effective management of risks associated with a harsh winter or a lack of spring rains, while yielding a more valued agricultural product. When barley was planted, in much lesser quantities, ethnographic analogy suggests that it was mainly a fodder crop (Morrison, 1939), although it may also have been used in beer brewing, as is attested at Phrygian Gordion (McGovern et al., 
1999; Sams, 1977), and for human consumption during particularly unproductive years. We assume that other plant foods were consumed at the site, including both farmed crops (e.g., lentils, but also vegetables underrepresented in charred seed assemblages) and collected fruits (e.g., cornelian cherries), while animal products likely provided the main source of protein at Kerkenes, despite limited archaeological evidence for these classes of remains.

That herded animals played a major role in subsistence and domestic economy at Kerkenes is evident, despite limited faunal analysis to date due to the heavily fragmented and burned animal bone assemblages. Iconographic representations of sheep and goats (Dusinberre, 2002), together with evidence for farming of fodder crops and ethnographic accounts for premechanized regional subsistence, suggest a major role for animals in the local economy. Incorporating animals, especially hardy sheep and goats, into an agropastoral subsistence strategy buffers risk by diversifying food sources both temporally and spatially, mitigating the effects of spatiotemporally localized drought, hail, and floods (Marston, 2011). Ethnographic accounts (Morrison, 1939; Yakar, 2000) attest to the value of herds in both risk buffering and textile production, which provided a valuable trade commodity, increasing local wealth and further mitigating temporary environmental risks attendant to the location and climate of Kerkenes.

So which agricultural practices did the Phrygians who originally settled Kerkenes bring with them from their homeland to the west? Archaeobotanical analysis of plant remains from the well-published site of Gordion provides a valuable comparative perspective on lowland Phrygian agriculture (Table 2; see also Marston, in press; Miller, 2010). We find a similar assemblage of crop types and land use practices at Middle Phrygian Gordion and Kerkenes: cereal agriculture was dominant, pulses included both lentil and bitter vetch, and wood was the predominant fuel 
(although other periods of occupation at Gordion indicate much higher reliance on dung for fuel; Marston, in press; Miller, 1999, 2010; Miller and Marston, 2012). Thus it appears that Phrygian settlers at Kerkenes brought with them the same general approach to agriculture and suite of cultigens familiar from lowland Phrygia.

Several distinct agricultural strategies are also evident, however. While agriculture at Gordion also primarily focused on cereal production, barley was more common than wheat (1.69:1 ratio by weight) and pulses (standardized to cereal weight) almost five times more frequent than at Kerkenes (Table 2). Lentils were more ubiquitous and numerous than vetch in Middle Phrygian contexts at Gordion (Marston, in press), indicating that pulse agriculture was certainly intended for human food, as well as likely animal fodder on occation (Miller, 2010). Wild seeds resulting from burned animal dung are more frequent finds at Gordion, demonstrating the intensity of animal grazing in the region (Marston, 2012). These strategies illustrate an agropastoral system designed to mitigate the risk of drought, both by diversifying food sources and emphasizing cultivation of hardy, drought-tolerant crops (especially barley) as well as mobile, dryland adapted sheep and goat husbandry (Marston, 2011; Miller et al., 2009; Zeder and Arter, 1994). Ethnographic evidence from the $20^{\text {th }}$ century also supports climate-based differentiation in cereal agriculture between these areas. In the 1950s, inhabitants of Yassihöyük (the modern village at the site of ancient Gordion) planted slightly more land in wheat than barley, at roughly a 1.5:1 ratio, much less than the roughly $10: 1$ ratio of land in wheat to barley in Alişar, near Kerkenes (METU, 1965, p. 64; Morrison, 1939, pp. 17-27). Environmental variation between the two areas appears to have dictated cereal agriculture strategies even into the early era of mechanized farming. 
Kaman Kalehöyük, another lowland Iron Age site (c. 1100 m elevation) with evidence for Phrygian control (Fig. 1; Kealhofer and Grave, 2011; Omura, 2011; Roller, 2011), provides additional corroboration of a Phrygian lowland agricultural strategy. Although published only in preliminary form to date, data show that barley was more common than wheat, both lentil and bitter vetch were grown, and wild seeds were common, indicating prevalent dung fuel use (Fairbairn, 2006; Fairbairn and Bradley, 2008; Üstünkaya, 2015; Wright et al., 2015). This pattern follows that of Gordion, rather than Kerkenes, suggesting that climatic similarities between Gordion and Kaman, both in the lowland steppe-forest zone, led to similar agricultural adaptations at the two sites. Kerkenes, however, presented unique opportunities and challenges due to its climate and topography, and Phrygian settlers drew upon their existing toolbox of agricultural products to devise a new set of agricultural strategies for this novel landscape.

To summarize these observations, it appears that cultural continuity within the Phrygian kingdom did not preclude agricultural experimentation and adaptation to local climatic conditions. While drought was the primary risk in lowland Anatolia, where rainfall may have been insufficient for wheat agriculture more than one year in ten (Marston, in press), drought was only a seasonal risk at Kerkenes, as were late frosts and the resulting abbreviated growing season. The wetter climate of Kerkenes reduced environmental risk and afforded increased wheat cultivation, leading to little need for barley to have been grown for human consumption. Inhabitants of the site negotiated their initially unfamiliar environment by deploying traditional knowledge about the responses of their established crops to variable climatic conditions, perhaps merged with local traditional knowledge gained from indigenous inhabitants of the Kerkenes region, allowing rapid adaptation and agricultural success in a new landscape. That Kerkenes was such a large city atop a high mountain ridge, and yet came to an end via fiery destruction 
rather than gradual abandonment, attests to the success of Kerkenes' farmers and herders in adapting to local environmental conditions, at least during the century during which the city was occupied.

\section{Conclusions}

Kerkenes presents a prime opportunity to explore how settlers adapt agricultural systems to climatic conditions distinct from those of their homeland. Phrygian colonists moving to the highlands of Kerkenes from the western lowlands brought with them plants and animals used in drought-mitigating agricultural strategies adapted to the Gordion region. At Kerkenes, however, increased precipitation provided new agricultural opportunities at the same time that the shorter growing season and increased frost risk limited the range of crops viable at high elevations and necessitated foddering of animals over long winters. The resulting agricultural strategy, focused on wheat agriculture together with fodder crops, was successful during the short period that Kerkenes was inhabited prior to its violent destruction.

This exploration of agricultural adaptation at Kerkenes has implications for understanding the role of agropastoral systems in state expansion within Iron Age Anatolia, as well as the comparative study of how large, complex polities expand beyond their initial geographic zone. While prior historical work on the Hittite and Assyrian empires has elucidated their agricultural policies (Hoffner, 1974; Liverani, 1979; Reculeau, 2011), little attention has been paid to role of agriculture in the expansion of the Phrygian state, due in large part to its lack of documentary records. Building on extensive prior work at the Phrygian capital of Gordion (Marston, 2012, in press; Miller, 2010), we now have a comparative context to identify what a 
"Phrygian" agricultural system might be, and how it was adapted across the diverse geography and climate of Central Anatolia. Further work at sites with evidence for Phrygian influence, including Daskyleion, Kaman Kalehöyük, Boğazköy (the Hittite capital Hattusa), and Çadır Höyük, will provide additional insight into regional differentiation in agricultural practices across Iron Age Anatolia and how the Phrygian agricultural economy was structured spatially.

The comparative approach to agriculture in climatically distinct regions within a large polity adopted here is suitable for application to other large, territorial states across the Near East, and further afield. Such an approach would be especially fruitful within the context of welldocumented states where agricultural and taxation records can be connected with rich archaeobotanical assemblages. Comparing our conclusions with the earlier example of highland southwest China highlights the broad applications of archaeobotany and climate modeling to understand not only when, but also how and why, agricultural practices spread across regions. Similar regional, comparative studies are especially promising within imperial settings, where centers of agricultural decision making may be significantly divorced, at both spatial and organizational levels, from day-to-day practices of farmers and herders. The economic, political, and environmental dynamics that mediate that relationship may result in unsustainable agricultural outcomes (e.g., Marston and Miller, 2014), and to explore these dynamics across time and space may offer new insights into the success or failure of empires worldwide.

\section{Acknowledgements}

We thank the Turkish Ministry of Culture and Tourism for excavation permits at both Kerkenes and Gordion, and the project and excavation directors of Gordion, G. Kenneth Sams, 
C. Brian Rose, and Mary M. Voigt, for their support of Marston's prior work at Gordion. The excavations from which this data was collected at Kerkenes in 2010 and 2011 were funded by the Women's Board of the University of Chicago, the Oriental Institute, the UCLA Cotsen Institute of Archaeology, Andrea Dudek, Catherine Novotny Brehm, John Kelly, John Notz, Hazel Bertz, and an anonymous donor. Marston's research at Gordion was supported by the US National Science Foundation (BCS-0832125), while the Council of American Overseas Research Centers, the American Philosophical Society, and Boston University funded work at both Kerkenes and Gordion. We thank Mary M. Voigt and Naomi F. Miller, as well as five anonymous reviewers, for their comments on earlier versions of this text. 
Table 1. Climate data from Yozgat and Polatlı weather stations, approximating average weather at Kerkenes and Gordion. Note that Gordion lies $200 \mathrm{~m}$ lower in elevation than Polatl so is warmer and drier than estimated here. Polatl data from Turkish General Directorate of Meteorology, 2006 and Yozgat data from Turkish General Directorate of Meteorology, 2016; Yozgat Governate Directorate of Provincial Disaster and Emergency, 2016.

\begin{tabular}{|l|r|r|}
\hline & Yozgat (Kerkenes) & Polatl (Gordion) \\
\hline Elevation (masl) & 1298 & 885 \\
\hline Mean annual rainfall $(\mathrm{mm})$ & 573.8 & 354.8 \\
\hline Mean annual temperature $\left({ }^{\circ} \mathrm{C}\right)$ & 9.1 & 11.5 \\
\hline Months with mean daily temperature $<5^{\circ} \mathrm{C}$ & 5 & 3 \\
\hline Mean annual days with snow cover & 57.4 & 28.8 \\
\hline
\end{tabular}


Table 2. Summary statistics of carbonized seeds identified at Kerkenes and Gordion (Middle Phrygian period only, c. 850-540 BC). Gordion data from Marston, in press and Miller, 2010; both sources provide full, sample-by-sample datasets.

\begin{tabular}{|c|c|c|}
\hline & Kerkenes & Gordion \\
\hline Number of samples & 71 & 43 \\
\hline Total soil volume (L) & 663 & 312 \\
\hline \multicolumn{3}{|l|}{ Free-threshing wheat } \\
\hline Ubiquity & $44 \%$ & $74 \%$ \\
\hline Count & 236 & 82 \\
\hline Weight (g) & 2.37 & 1.32 \\
\hline \multicolumn{3}{|l|}{ Barley } \\
\hline Ubiquity & $25 \%$ & $79 \%$ \\
\hline Count & 54 & 66 \\
\hline Weight (g) & 0.56 & 2.23 \\
\hline \multicolumn{3}{|l|}{ Pulses } \\
\hline Ubiquity & $14 \%$ & $56 \%$ \\
\hline Count & 11 & 16 \\
\hline Weight (g) & 0.06 & 0.40 \\
\hline Total crop seeds (ct) & 370 & 218 \\
\hline Total wild seeds (ct) & 247 & 1005 \\
\hline Charred density $(\mathrm{g} / \mathrm{l})$ & 0.33 & 2.24 \\
\hline Wild seed:charcoal ratio (\#/g) & 1.12 & 1.55 \\
\hline Seed:charcoal (g/g) & 0.02 & 0.02 \\
\hline Barley:wheat ratio $(\mathrm{g} / \mathrm{g})$ & 0.24 & 1.69 \\
\hline Cereal:pulse ratio $(\mathrm{g} / \mathrm{g})$ & 86.7 & 18.1 \\
\hline Wild seed:cereal ratio (\#/g) & 48.3 & 150.0 \\
\hline
\end{tabular}




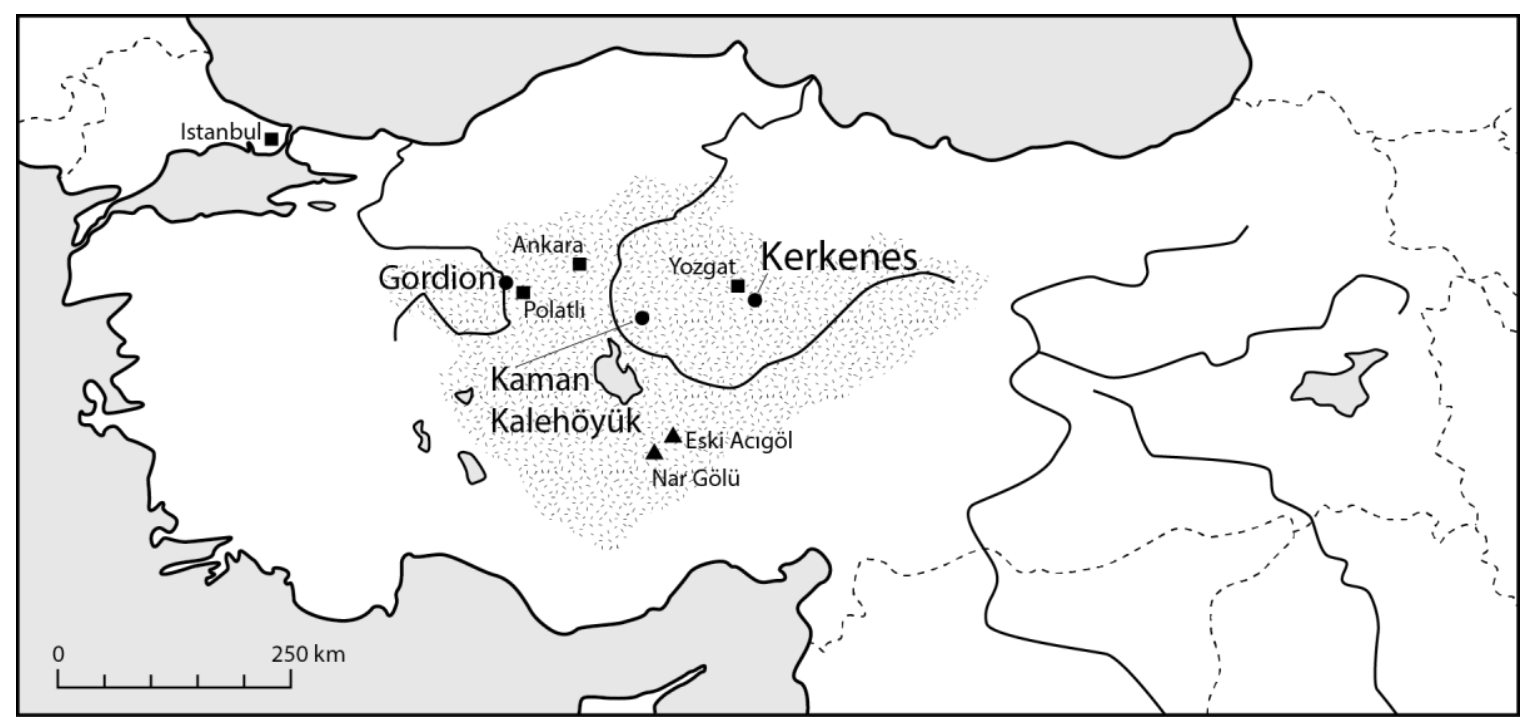

Fig. 1. Map of Turkey depicting Central Anatolia (hatched), sites with data mentioned in text (dots), pollen core sites (triangles), and modern cities (squares). 


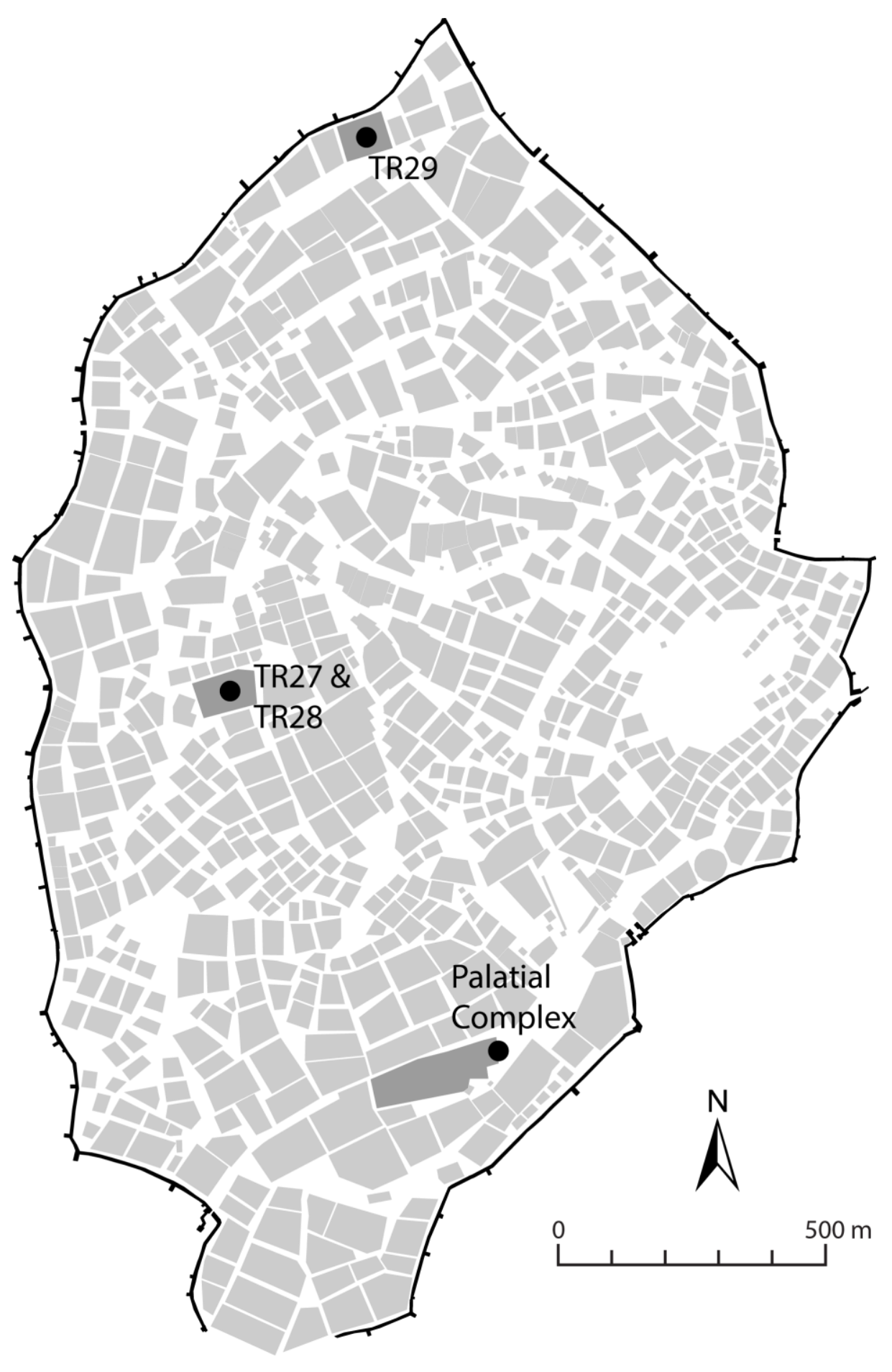

Fig. 2. City plan of Kerkenes, with areas of archaeobotanical sampling marked in dark grey; trenches TR27, TR28, and TR29 provide the new data presented in this article, while Palatial Complex finds are reported in Smith and Branting, 2014. 


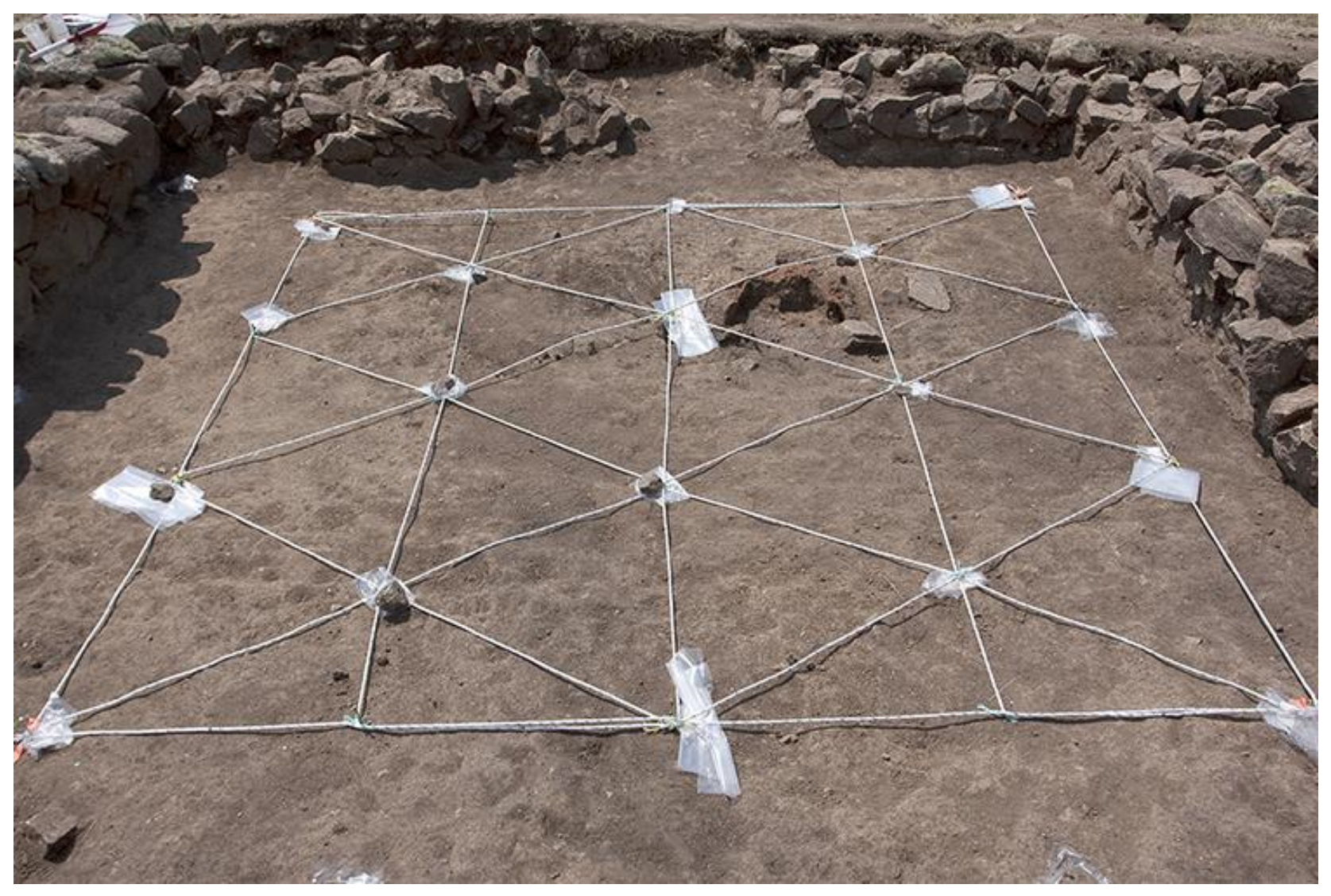

Fig. 3. Implementation of the hexagonal grid used to take flotation samples from the destruction level within Trench 29 in 2011. 


\section{References Cited}

Alcock, S.E., D'Altroy, T.N., Morrison, K.D., Sinopoli, C.M., (Eds.), 2009. Empires:

Perspectives from Archaeology and History. Cambridge University Press, Cambridge.

Algaze, G., 2005. The Uruk World System: The Dynamics of Expansion of Early Mesopotamian Civilization. University of Chicago Press.

Allcock, S.L., 2013. Living with a changing landscape: Holocene climate variability and socioevolutionary trajectories, central Turkey. Unpublished Ph.D. Dissertation, School of Geography, Earth and Environmental Sciences, Plymouth University, Plymouth, UK.

Arbuckle, B.S., Öztan, A., Gülçur, S., 2009. The evolution of sheep and goat husbandry in central Anatolia. Anthropozoologica 44, 129-157.

Atalay, I., 1997. Türkiye Bölgesel Coğrafyası. İnkılap Kitabevi, İstanbul.

Atalay, I., 2001. The ecology of forests in Turkey. Silva Balcanica 1, 25-34.

Bentley, R.A., 2006. Strontium isotopes from the earth to the archaeological skeleton: a review. Journal of Archaeological Method and Theory 13, 135-187.

Branting, S., 2010. Kerkenes Dağ Project. In: Stein, G., (Ed.), The Oriental Institute 2010-2011 Annual Report. Oriental Institute Press, Chicago, pp. 70-80.

Branting, S., Özarslan, Y., Marston, J.M., Lehner, J.W., Graff, S.R., in press. Kerkenes and Phrygia: old and new directions of research. In: Tsetskhladze, G.R., (Ed.), The Phrygian Lands over Time: From Prehistory to the Middle of the 1st Millennium AD. Peeters, Leuven.

Butzer, K.W., 2005. Environmental history in the Mediterranean world: cross-disciplinary investigation of cause-and-effect for degradation and soil erosion. Journal of Archaeological Science 32, 1773-1800.

Cappers, R.T.J., Bekker, R.M., Jans, J.E.A., 2006. Digital Seed Atlas of the Netherlands. Barkhuis Publishing, Eelde.

Casana, J., 2008. Mediterranean valleys revisited: Linking soil erosion, land use and climate variability in the Northern Levant. Geomorphology 101, 429-442.

Chen, F.H., Dong, G.H., Zhang, D.J., Liu, X.Y., Jia, X., An, C.B., Ma, M.M., Xie, Y.W., Barton, L., Ren, X.Y. and others, 2015. Agriculture facilitated permanent human occupation of the Tibetan Plateau after 3600 B.P. Science 347, 248-250.

d'Alpoim Guedes, J., 2015. Rethinking the spread of agriculture to the Tibetan Plateau. The Holocene 25, 1498-1510.

d'Alpoim Guedes, J., Butler, E.E., 2014. Modeling constraints on the spread of agriculture to Southwest China with thermal niche models. Quaternary International 349, 29-41.

d'Alpoim Guedes, J., Jiang, M., He, K., Wu, X., Jiang, Z., 2013. Site of Baodun yields earliest evidence for the spread of rice and foxtail millet agriculture to south-west China. Antiquity 87, 758-771.

d'Alpoim Guedes, J., Lu, H., Hein, A.M., Schmidt, A.H., 2015. Early evidence for the use of wheat and barley as staple crops on the margins of the Tibetan Plateau. Proceedings of the National Academy of Sciences 112, 5625-5630.

d'Alpoim Guedes, J., Lu, H., Li, Y., Spengler, R.N., Wu, X., Aldenderfer, M.S., 2014. Moving agriculture onto the Tibetan plateau: the archaeobotanical evidence. Archaeological and Anthropological Sciences 6, 255-269. 
d'Alpoim Guedes, J., Spengler, R.N., 2014. Sampling strategies in paleoethnobotanical analysis. In: Marston, J.M., d'Alpoim Guedes, J., Warinner, C., (Eds.), Method and Theory in Paleoethnobotany. University Press of Colorado, Boulder, pp. 77-94.

Davis, P.H., 1965-2000. Flora of Turkey and the East Aegean Islands. Edinburgh University Press, Edinburgh.

Dunning, N.P., Beach, T.P., Luzzadder-Beach, S., 2012. Kax and kol: collapse and resilience in lowland Maya civilization. Proceedings of the National Academy of Sciences of the United States of America 109, 3652-3657.

Dusinberre, E.R.M., 2002. An excavated ivory from Kerkenes Dağ, Turkey: transcultural fluidities, significations of collective identity, and the problem of Median art. Ars Orientalis 32, 17-54.

Fairbairn, A., 2006. Archaeobotany at Kaman-Kalehöyük 2005. Anatolian Archaeological Studies 15, 133-137.

Fairbairn, A., Bradley, K., 2008. Archaeobotany at Kaman-Kalehöyük 2007. Anatolian Archaeological Studies 17, 195-199.

Finné, M., Holmgren, K., Sundqvist, H.S., Weiberg, E., Lindblom, M., 2011. Climate in the eastern Mediterranean, and adjacent regions, during the past 6000 years - a review. Journal of Archaeological Science 38, 3153-3173.

Fiorentino, G., Ferrio, J.P., Bogaard, A., Araus, J.L., Riehl, S., 2015. Stable isotopes in archaeobotanical research. Vegetation History and Archaeobotany 24, 215-227.

Fırıncıoğlu, H.K., Seefeldt, S.S., Şahin, B., 2007. The Effects of Long-Term Grazing Exclosures on Range Plants in the Central Anatolian Region of Turkey. Environmental Management 39, 326-337.

Foley, J.A., DeFries, R., Asner, G.P., Barford, C., Bonan, G., Carpenter, S.R., Chapin, F.S., Coe, M.T., Daily, G.C., Gibbs, H.K. and others, 2005. Global consequences of land use. Science 309, 570-574.

Gallant, T.W., 1991. Risk and Survival in Ancient Greece: Reconstructing the Rural Domestic Economy. Stanford University Press, Palo Alto.

Halstead, P., Jones, G., 1989. Agrarian ecology in the Greek islands: time stress, scale and risk. Journal of Hellenic Studies 109, 41-55.

Hoffner, H.A., 1974. Alimenta Hethaeorum: Food Production in Hittite Asia Minor. American Oriental Society, New Haven.

Iannone, G., Prufer, K., Chase, D.Z., 2014. Resilience and vulnerability in the Maya hinterlands. Archeological Papers of the American Anthropological Association 24, 155-170.

Johnson, A.C., 1936. An Economic Survey of Ancient Rome. Volume 2, Roman Egypt to the Reign of Diocletian. The Johns Hopkins Press, Baltimore.

Kaniewski, D., Paulissen, E., Van Campo, E., Weiss, H., Otto, T., Bretschneider, J., Van Lerberghe, K., 2010. Late second-early first millennium BC abrupt climate changes in coastal Syria and their possible significance for the history of the Eastern Mediterranean. Quaternary Research 74, 207-215.

Kealhofer, L., Grave, P., 2011. The Iron Age on the Central Anatolian Plateau. In: Steadman, S., McMahon, G., (Eds.), The Oxford Handbook of Ancient Anatolia (10,000-323 BCE). Oxford University Press, Oxford, pp. 415-442.

Liverani, M., 1979. The ideology of the Assyrian empire. In: Larsen, M.T., (Ed.), Power and Propaganda: A Symposium on Ancient Empires. Akademisk Forlag, Copenhagen, pp. 297-317. 
Marsh, B., Kealhofer, L., 2014. Scales of impact: Settlement history and landscape change in the Gordion Region, central Anatolia. The Holocene 24, 689-701.

Marston, J.M., 2011. Archaeological markers of agricultural risk management. Journal of Anthropological Archaeology 30, 190-205.

Marston, J.M., 2012. Agricultural strategies and political economy in ancient Anatolia. American Journal of Archaeology 116, 377-403.

Marston, J.M., 2014. Ratios and simple statistics in paleoethnobotanical analysis: data exploration and hypothesis testing. In: Marston, J.M., d'Alpoim Guedes, J., Warinner, C., (Eds.), Method and Theory in Paleoethnobotany. University Press of Colorado, Boulder, pp. 163-179.

Marston, J.M., 2015. Modeling resilience and sustainability in ancient agricultural systems. Journal of Ethnobiology 35, 585-605.

Marston, J.M., in press. Agricultural Sustainability and Environmental Change at Ancient Gordion. University of Pennsylvania Museum Press, Philadelphia.

Marston, J.M., Miller, N.F., 2014. Intensive agriculture and land use at Roman Gordion, Central Turkey. Vegetation History and Archaeobotany 23, 761-773.

Marston, J.M., Warinner, C., d'Alpoim Guedes, J., (Eds.), 2014. Method and Theory in Paleoethnobotany. University Press of Colorado, Boulder.

McGovern, P.E., Glusker, D.L., Moreau, R.A., Nuñez, A., Beck, C.W., Simpson, E., Butrym, E.D., Exner, L.J., Stou, E.C., 1999. A funerary feast fit for King Midas. Nature 402, 863864.

METU, 1965. Yassıhöyük: A Village Study. Middle East Technical University, Ankara.

Miller, F., Osbahr, H., Boyd, E., Thomalla, F., Bharwani, S., Ziervogel, G., Walker, B., Birkmann, J., van der Leeuw, S., Rockström, J. and others, 2010. Resilience and Vulnerability: Complementary or Conflicting Concepts? Ecology and Society 15, 11.

Miller, N.F., 1988. Ratios in paleoethnobotanical analysis. In: Hastorf, C.A., Popper, V.S., (Eds.), Current Paleoethnobotany: Analytical Methods and Cultural Interpretations of Archaeological Plant Remains. University of Chicago Press, Chicago, pp. 72-96.

Miller, N.F., 1997. Farming and herding along the Euphrates: environmental constraint and cultural choice (fourth to second millennia B.C.). MASCA Research Papers in Science and Archaeology 14, 123-132.

Miller, N.F., 1999. Interpreting ancient environment and patterns of land use: seeds, charcoal and archaeological context. TÜBA-AR 2, 15-27.

Miller, N.F., 2010. Botanical Aspects of Environment and Economy at Gordion, Turkey. University of Pennsylvania Museum of Archaeology and Anthropology, Philadelphia.

Miller, N.F., 2013. Agropastoralism and archaeobiology: connecting plants, animals and people in west and central Asia. Environmental Archaeology 18, 247-256.

Miller, N.F., Enneking, D., 2014. Bitter vetch (Vicia ervilia): ancient medicinal crop and farmers' favorite for feeding livestock. In: Minnis, P.E., (Ed.), New Lives for Ancient and Extinct Crops. University of Arizona, Tucson, pp. 254-268.

Miller, N.F., Marston, J.M., 2012. Archaeological fuel remains as indicators of ancient West Asian agropastoral and land-use systems. Journal of Arid Environments 86, 97-103.

Miller, N.F., Zeder, M.A., Arter, S.R., 2009. From food and fuel to farms and flocks: the integration of plant and animal remains in the study of the agropastoral economy at Gordion, Turkey. Current Anthropology 50, 915-924. 
Morrison, J.A., 1939. Alişar: A Unit of Land Occupance in the Kanak Su Basin of Central Anatolia. Unpublished Ph.D. dissertation, Department of Geography, University of Chicago, Chicago.

Nesbitt, M., 2006. Identification Guide for Near Eastern Grass Seeds. Institute of Archaeology, University College London, London.

Omura, S., 2011. Kaman-Kalehöyük excavations in Central Anatolia. In: Steadman, S., McMahon, G., (Eds.), The Oxford Handbook of Ancient Anatolia (10,000-323 BCE). Oxford University Press, Oxford, pp. 1095-1111.

Pearsall, D.M., 2015. Paleoethnobotany: a Handbook of Procedures. Left Coast Press, Walnut Creek, CA.

Popper, V.S., 1988. Selecting quantitative measurements in paleoethnobotany. In: Hastorf, C.A., Popper, V.S., (Eds.), Current Paleoethnobotany: Analytical Methods and Cultural Interpretations of Archaeological Plant Remains. University of Chicago Press, Chicago, pp. 53-71.

Porter, J.R., Xie, L., Challinor, A.J., Cochrane, K., Howden, S.M., Iqbal, M.M., Lobell, D.B., Travasso, M.I., 2014. Food security and food production systems. In: Field, C.B., Barros, V.R., Dokken, D.J., Mach, K.J., Mastrandrea, M.D., Bilir, T.E., Chatterjee, M., Ebi, K.L., Estrada, Y.O., Genova, R.C. and others, (Eds.), Climate Change 2014: Impacts, Adaptation, and Culnerability. Part A: Global and Sectoral Aspects. Contribution of Working Group II to the Fifth Assessment Report of the Intergovernmental Panel on Climate Change. Cambridge University Press, Cambridge, pp. 485-533.

Reculeau, H., 2011. Climate, Environment, and Agriculture in Assyria. Harrassowitz Verlag, Wiesbaden.

Redman, C.L., Kinzig, A.P., 2003. Resilience of past landscapes: resilience theory, society, and the Longue Duree. Conservation Ecology 7, 14.

Redman, C.L., Nelson, M.C., Kinzig, A.P., 2009. The resilience of socioecological landscapes: lessons from the Hohokam. In: Fisher, C.T., Hill, J.B., Feinman, G.M., (Eds.), The Archaeology of Environmental Change: Socionatural Legacies of Degradation and Resilience. University of Arizona Press, Tucson, pp. 15-39.

Reimer, P.J., Bard, E., Bayliss, A., Beck, J.W., Blackwell, P.G., Bronk Ramsey, C., Buck, C.E., Cheng, H., Edwards, R.L., Friedrich, M. and others, 2013. IntCal13 and Marine13 radiocarbon age calibration curves 0-50,000 years cal BP. Radiocarbon 55, 1869-1887.

Riehl, S., 2009. Archaeobotanical evidence for the interrelationship of agricultural decisionmaking and climate change in the ancient Near East. Quaternary International 197, 93114.

Riehl, S., 2014. Significance of prehistoric weed floras for the reconstruction of relations between environment and crop husbandry practices in the Near East. In: Madella, M., Lancelotti, C., Savard, M., (Eds.), Ancient Plants and People: Contemporary Trends in Archaeobotany. University of Arizona Press, Tucson, pp. 135-152.

Roberts, N., Eastwood, W.J., Kuzucuoğlu, C., Fiorentino, G., Caracuta, V., 2011. Climatic, vegetation and cultural change in the eastern Mediterranean during the mid-Holocene environmental transition. The Holocene 21, 147-162.

Roberts, N., Reed, J.M., Leng, M.J., Kuzucuoğlu, C., Fontugne, M., Bertaux, J., Woldring, H., Bottema, S., Black, S., Hunt, E. and others, 2001. The tempo of Holocene climatic change in the eastern Mediterranean region: new high-resolution crater-lake sediment data from central Turkey. The Holocene 11, 721-736. 
Roller, L.E., 2011. Phrygian and the Phrygians. In: Steadman, S., McMahon, G., (Eds.), The Oxford Handbook of Ancient Anatolia (10,000-323 BCE). Oxford University Press, Oxford, pp. 560-578.

Rose, C.B., (Ed.), 2012. The Archaeology of Phrygian Gordion, Royal City of Midas. University of Pennsylvania Press, Philadelphia.

Sams, G.K., 1977. Beer in the city of Midas. Archaeology 30, 108-115.

Sinopoli, C.M., 1994. The archaeology of empires. Annual Review of Anthropology 23, 159180.

Smith, A., Branting, S., 2014. Some Phrygian plant and insect remains from Kerkenes Dă̆, central Anatolia (Turkey). Ethnobiology Letters 5, 44-51.

Smith, M.E., Montiel, L., 2001. The archaeological study of empires and imperialism in preHispanic central Mexico. Journal of Anthropological Archaeology 20, 245-284.

Summers, G.D., 2006. Phrygian expansion to the east: evidence of cult from Kerkenes Dağ. Baghdader Mitteilungen 37, 647-658.

Summers, G.D., 2013. Connectivity and cultural isolation at Kerkenes, an Iron Age capital in central Turkey. In: Bombardieri, L., D'Agostino, A., Guarducci, G., Orsi, V., Valentini, S., (Eds.), SOMA 2012. Identity and Connectivity: Proceedings of the 16th Symposium on Mediterranean Archaeology, Florence, Italy, 1-3 March 2012. Archaeopress, Oxford, pp. 225-232.

Summers, G.D., Branting, S., Baltalı Tırpan, S., Baturayoğlu Yöney, N., Lehner, J.W., 2012. Kerkenes 2010. Kazı Sonuçları Toplantısı 33, 535-558.

Summers, G.D., Summers, F., 2013. The kale at Kerkenes Dağ: an Iron Age capital in Central Anatolia. In: Redford, S., Ergin, N., (Eds.), Cities and Citadels in Turkey: From the Iron Age to the Seljuks. Peeters, Leuven, pp. 137-159.

Turkish General Directorate of Meteorology. 2006. Polatlı meteorological records, 1964-2005. Polatl1, Turkey: Unpublished dataset from Polatlı Meteorological Station.

Turkish General Directorate of Meteorology, 2016. Statistical data regarding our provinces. http://www.mgm.gov.tr/veridegerlendirme/il-ve-ilceler-istatistik.aspx. Accessed 201619 January.

Üstünkaya, M.C., 2015. Investigating Climate Related Agricultural Stress Patterns at Bronze and Iron Age Kaman-Kalehöyük: The Integration of Botanical Stable Carbon and Nitrogen Isotope Values, Grain Weight Values, and Seed Analysis. Unpublished PhD dissertation, Department of Archaeology, University of Queensland, Brisbane.

van Zeist, W., Bottema, S., 1991. Late Quaternary Vegetation of the Near East. Dr. Ludwig Reichert Verlag, Wiesbaden.

Warinner, C., 2014. From the ground up: advances in stable isotope-based paleodietary inference. In: Marston, J.M., d'Alpoim Guedes, J., Warinner, C., (Eds.), Method and Theory in Paleoethnobotany. University Press of Colorado, Boulder, pp. 275-291.

Weiss, B., 1982. The decline of Late Bronze Age civilization as a possible response to climatic change. Climatic Change 4, 173-198.

Wright, N.J., Fairbairn, A.S., Üstünkaya, M.C., Faith, J.T., 2015. Explaining changing patterns of wood presence across the Bronze and Iron Age at Kaman-Kalehöyük, central Anatolia. Quaternary International online before print.

Yakar, J., 2000. Ethnoarchaeology of Anatolia: Rural Socio-economy in the Bronze and Iron Ages. Institute of Archaeology of Tel Aviv University, Publications Section, Tel Aviv. 
Young, R.S., 1981. The Gordion excavations final reports, vol. I: three great early tumuli. University of Pennsylvania Museum of Archaeology and Anthropology, Philadelphia.

Yozgat Governate Directorate of Provincial Disaster and Emergency, 2016. Yozgat province disaster. http://www.yozgatafetacil.gov.tr/default_B0.aspx?content=89. Accessed 2016 30 January.

Zeder, M.A., 1991. Feeding Cities: Specialized Animal Economy in the Ancient Near East. Smithsonian Institution Press, Washington.

Zeder, M.A., Arter, S.R., 1994. Changing patterns of animal utilization at ancient Gordion. Paléorient 22, 105-118.

Zohary, M., 1973. Geobotanical Foundations of the Middle East. G. Fischer, Stuttgart. 